\title{
EFFECT OF RAISED BED PLANTING TECHNOLOGY ON PRODUCTIVITY, MACRO NUTRIENTS UPTAKE OF BREAD WHEAT AND SAVING IRRIGATION WATER
}

Osman, E. A.M.* A. A . Swelam**,Manal, A .Hassan** and Sheren, N. Nathan** (1) *Soils, water and Environment Research Institute, Agric. Res. Center, Giza, Egypt.

**Wheat res. Deb., Field Crop Research Institute, Agric. Res. Center, Giza, Egypt.

\section{ABSTRACT:}

On-farm field experiments were conducted to assess the effects of planting methods (raised bed and farmer practices) on yield and macro nutrients uptake of bread wheat, as well as amount of applied water. The locations of the experiments were in ten farmers' field representing ten districts at Al- Sharkia Governorate, Egypt, durinig 2011/2012 and 2012/2013 seasons.

\section{The obtained results could be summarized as follows:}

1-Sowing wheat on raised bed was superior in its productivity compared with farmer practices (traditional sowing) at all locations under study in both seasons. The relative increase of wheat productivity for raised bed were 23.21, 24.70 and $23.98 \%$ for grain, straw and biological yield, respectively in the $1^{\text {st }}$ season, as well as $34.63,32.99$ and $33.78 \%$ for grain, straw and biological yield, in the $2^{\text {nd }}$ season, respectively.

2-Raised bed treatment gave the highest values of nitrogen, phosphorus and potassium uptake for grain, straw and biological wheat yield compared to farmer practices in both seasons. The relative increase of $\mathrm{N}$ uptake for wheat grown on raised bed were $38.85,52.22$ and $41.41 \%$ in the $1^{\text {st }}$ season, as well as $49.28,50.99$ and $41.19 \%$ in the $2^{\text {nd }}$ season for grain, straw and biological yield, respectively. The relative increase of phosphorus uptake for wheat grown on raised bed were $24.23,24.90$ and $24.48 \%$ in the $1^{\text {st }}$ season and $34.41,39.53$ and $36.39 \%$ in the $2^{\text {nd }}$ season for grain, straw and biological yield, respectively in the $2^{\text {nd }}$ season. The relative increase of $\mathrm{K}$ uptake for wheat grown on raised bed was $59.00,47.87$ and $50.08 \%$ in the $1^{\text {st }}$ season, as well as $36.53,40.59$ and $39.82 \%$ in the $2^{\text {nd }}$ season for grain, straw and biological yield, respectively.

3-Raised bed treatment gave the higher saving in irrigation water more than the farmer practices treatment in both seasons. The applied water for wheat sowing on raised bed was lower than flat treatment by 1356 and $1212 \mathrm{~m}^{3} \mathrm{ha}^{-1}$ with savings of irrigation water by 24.1 and $23.7 \%$ in the first and second season, respectively.

\section{INTRODUCTION}

Wheat is an important cereal crops which is grown on more hectares globally than any other crops and provides a major share of the nutritional

$\left({ }^{1}\right)$ This work is part of the activities of ('Enhancing food security in Arab Countries)) project phase, conducted in Al-Sharkia governorate, Egypt

Fayoum J. Agric. Res. \& Dev., Vol. 29, No.1, January, 2015 
Osman, E. A.M et al.,

necessities for the growing world population (Shapiro, 2009). It is a staple food for about one third of the world's population (Hussain and Shah. 2002), being cultivated in Egypt on about 1.25 million hectare and delivering about 8.1 million ton of grain yields. However, the Egyptian government is forced to import wheat every year because of high demand supply gap. To feed the growing human population and fill the yield gaps between wheat consumption and production in Egypt, increasing production of wheat is very important. Moreover, wheat straw is an integral component of livestock feed. Increasing wheat production can be possible by increasing productivity of small holder producers by vertical extension in the old soils where wheat production is constrained by both biotic and abiotic stress.

Surface irrigation is the conventional irrigation method in about $80 \%$ of the irrigated area in Egypt. It is characterized by lower water application efficiency (45 to $50 \%$ ) compared to the other methods, mainly because of water loss due to deep percolation and evapotranspiration. Farmers are usually seen to over-irrigate their fields, which leads to greater losses leading to profile drainage, which in turn increases water storage that cannot be taken up by crops. Consequently, optimal irrigation application, during the growing season, is important for increasing wheat productivity per unit of applied water without additional costs (Swelam and Atta 2011). When using the raised bed planting method technology, higher yield, lower water application and higher gross production water use indices for maize crop can be achieved (Ahmad et al. 2009; Akbar et al. 2010; Ahamd et al. 2011; Zhang et al. 2012). Regardless of irrigation intervals, several studies have shown the potential of the raised beds method in saving irrigation water and improving water use efficiency for different crops, i. e., sugar beet (Taleghani et al. 2004), oilseed rape (Buttar et al. 2006) and potato (Harms and Konschuh 2010). Abd ElHalim and Abd El-Razek, (2014). Raised bed planting method has been shown to improve water distribution and efficiency, fertilizer use efficiency, reduces weed infestation and lodging and it also reduces seed rate without sacrificing yield (Hobbs $\boldsymbol{e t}$ al. 2000). There are indications that the crop yield on raised beds can be further increased due to nutrient management and later irrigation because of the reduced hazard of lodging (Sayre and Mornes Romos, 1997). Changing to a raised bed planting method from traditional flat planting with flood irrigation can give water saving of 35\%. It also eliminates the formation of a crust on the surface of calcareous soils (Fahong, et al, 2003). So, the present study has been carried to measure the effect raised bed planting method in ten locations on increasing wheat yield, its nutritional states and saving irrigation water in old soil of Egypt.

\section{MATERIALS AND METHODS}

A field experiment was set up on farmers' fields with the full participation of farmers at different locations (Al-Sharkia Governorate, Egypt) during the two winter seasons, 2011/2012 and 2012/2013 to study the effect of raised bed planting technology and conventional method (flat) on wheat yield

Fayoum J. Agric. Res. \& Dev., Vol. 29, No.1, January, 2015 
EFFECT OF RAISED BED PLANTING TECHNOLOGY ON

(Triticum aestivum L.) cultivar Sids 12. Soil of the experimental field was sampled to determine particle size distribution and chemical analyses before planting according to the standard methods (Ryan et al., 1996) and the results are presented in Table (1).

The experimental plots were arranged in two planting methods (raised bed and flat) with four replicates in ten different locations ( Zagazig, Qnayat, Menya Al_Qamh, Mashtool, Abu Hammad, Belpis, Diarb Negm, Hehya, Abu Kabir and Faqous) in Al- Sharkia Governorate, Egypt. In the raised bed treatment wheat was planted on slightly raised bed $7 \mathrm{~m}$ length and $1.2 \mathrm{~m}$ wide separated by furrows, $25 \mathrm{~cm}$ deep and $30 \mathrm{~cm}$ wide at the top where the irrigation water was applied.

Surface irrigation was used with a calibrated cutthroat flume to measure water amounts for all plots. A standard rectangular cut-throat flume was installed at the inlet of the irrigation plots under free flow conditions. The depth of the water (Ha) was monitored and the discharge $(\mathrm{Q})$ was determined using the equation $\mathrm{Q}=\mathrm{CHa} 1.56$ where $\mathrm{C}$ is a fixed coefficient of the flume. FT (flat treatment) followed the normal practice where the farmer fills the basins frequently without taking into account the crop's requirements. However, amounts and timing were recorded.

Cultivar Sids 12 was sown at the rate of 100 and $150 \mathrm{~kg} \mathrm{ha}^{-1}$ for raised bed and flat treatments, respectively from $15^{\text {th }}$ to $28^{\text {th }}$ November in both seasons. The area of each plot was $84 \mathrm{~m}^{2}$.

Fertilizers used were based on the recommendations of the regional extension service, $180 \mathrm{~kg} \mathrm{~N}, 36 \mathrm{~kg} \mathrm{P}_{2} \mathrm{O}_{5}$ and $58 \mathrm{~kg} \mathrm{~K}_{2} \mathrm{O} \mathrm{ha}^{-1}$. Nitrogen fertilizer as ammonium nitrate $(33.5 \% \mathrm{~N})$, Phosphorus as superphosphate $\left(15 \% \mathrm{P}_{2} \mathrm{O}_{5}\right)$ and Potassium as potassium sulphate $\left(48 \% \quad \mathrm{~K}_{2} \mathrm{O}\right)$ were applied. Both phosphorus and potassium were added during soil preparation. Nitrogen was applied two times during the lifecycle of wheat $1^{\text {st }}$ time $2 / 3$ amount before the first irrigation and before the second irrigation. All cultural practices were carried out according to the recommendation of the wheat research department.

Plants of each plot were harvested, weighed to determine grain, straw and biological yields as well as harvest index.

Plant samples of grain and straw were digested to determine N, P and K. Nitrogen was determined using micro Kjeldahl, while phosphorous was determined colourimetrically using ammonium molybdate and ammonium metavanadate according to the procedure outlined by Ryan et al.,(1996). Potassium was determined using the flame spectrophotometry method (Black, 1982). $N, P$ and $K$ uptake of grain, straw and biological yield were calculated. In each plot, the amounts of water applied were measured.

Fayoum J. Agric. Res. \& Dev., Vol. 29, No.1, January, 2015 
Osman, E. A.M et al.,

Table 1

Fayoum J. Agric. Res. \& Dev., Vol. 29, No.1, January, 2015 
EFFECT OF RAISED BED PLANTING TECHNOLOGY ON .53 RESULTS AND DISCUSSION

\section{Bread wheat yield}

Data presented in Table 2 reveal that the wheat sowing on raised bed was superior to farmer practices (traditional sowing) in all locations under study in both seasons. The average mean values were 8.89, 9.68 and $18.57 \mathrm{t} \mathrm{ha}^{-1}$ for grain, straw and biological yield grown on raised bed, respectively compared to 7.21, 7.77 and $14.98 \mathrm{t} \mathrm{ha}^{-1}$ for the same yields sown with traditional sowing, respectively in the first season. Whereas, the average mean values were 9.50, 10.21 and $19.71 \mathrm{t} \mathrm{ha}^{-1}$ for grain, straw and biological yield grown on raised bed, respectively compared to $7.06,7.68$ and $14.73 \mathrm{t} \mathrm{ha}^{-1}$ for such yields grown with traditional sowing, respectively in the second one. The relative increase of wheat productivity resulted from raised bed were $23.21,24.70$ and $23.98 \%$ for grain, straw and biological yield, in the $1^{\text {st }}$ season respectively, also 34.63 , 32.99 and $33.78 \%$ to grain, straw and biological yield, respectively in the $2^{\text {nd }}$ one. Results in Table 2 show that the grain yield was increased by using raised bed planting method compared to traditional sowing treatment (farmer practices) with difference between them as follows $3.14,1.10,0.79,1.47,0.28$, 2.53, 2.50, 1.76, 1.75 and $1.42 \mathrm{t} \mathrm{ha}^{-1}$ for same ranked order of different locations in Table 2, respectively in the $1^{\text {st }}$ season, also 3.93, 2.30, 3.21, 2.32, $2.14,1.32,1.77,2.21,2.09$ and $3.22 \mathrm{t} \mathrm{ha}^{-1}$, respectively in the $2^{\text {nd }}$ one. The increase of wheat productivity on raised beds was possibly due to exposure of more surface area to incident solar radiation in raised bed than in flat conventional treatments. The higher temperature on raised bed planting method can help in early germination and seedling emergence, particularly in winter season crops such as wheat. These findings are in agreement with those obtained by Hossain, et al., (2006) who found that raised bed produced higher number of plants and spikes per square meter and maximum grain and straw yield than conventional methods. Also, Alam, (2012) concluded that grain yield was higher in raised bed planting system than conventional method due to increase in yield components.

Fayoum J. Agric. Res. \& Dev., Vol. 29, No.1, January, 2015 
Osman, E. A.M et al.,

Table (2) Effect of planting method on wheat productivity grown in different locations in both seasons

\begin{tabular}{|c|c|c|c|c|c|c|c|c|c|}
\hline \multirow{3}{*}{ Parameters } & \multicolumn{6}{|c|}{ Yield productivity ( $t$ / ha) } & \multirow{2}{*}{\multicolumn{3}{|c|}{ Relative increase (\%) }} \\
\hline & \multicolumn{3}{|c|}{ Raised beds } & \multicolumn{3}{|c|}{ Farmer practices } & & & \\
\hline & Grain & $\begin{array}{c}\text { Stra } \\
\mathbf{w} \\
\end{array}$ & Biol. & Grain & Straw & Biol. & \begin{tabular}{|c} 
Grai \\
n
\end{tabular} & Straw & Biol. \\
\hline \multicolumn{10}{|c|}{ First season } \\
\hline Zagazig & 10.77 & 11.95 & 22.72 & 7.63 & 8.21 & 15.84 & 41.15 & 45.55 & 43.43 \\
\hline Qnayat & 8.60 & 9.15 & 17.75 & 7.50 & 7.78 & 15.28 & 14.67 & 1761 & 5.16 \\
\hline Menya Al_Qamh & 8.64 & 9.68 & 18.32 & 7.85 & 12 & 15.97 & 10.06 & 19.21 & 14.72 \\
\hline Mashtool & 7.90 & 8.73 & 16.63 & 6.4 & .11 & 13.54 & 22.86 & 22. & 22.82 \\
\hline Abu Hamn & 8.57 & 9.10 & 17.67 & 8 & 35 & 17.14 & 3.38 & 2 & .09 \\
\hline Belpis & 10.03 & 10.91 & 20.94 & & & 15.82 & 33.73 & & .36 \\
\hline Diarb $N$ & 6.78 & 7.12 & 0 & 4 & & 8.87 & & & 71 \\
\hline Hehya & 10.02 & 10.75 & 20.77 & 8.2 & .53 & 16.79 & 21.31 & & .70 \\
\hline Abu Kabi & 8.96 & 9.88 & 18.84 & 7.2 & .00 & 15.21 & 24.27 & 23. & 3.87 \\
\hline Faqous & 8.59 & 9.56 & 18.15 & 7.1 & 7.64 & 14.81 & 19.80 & 25 & 2.55 \\
\hline Mean & 8.89 & 9.68 & 18.57 & 7.21 & 7.77 & 14.98 & 23.21 & 24.70 & 23.98 \\
\hline \multicolumn{10}{|c|}{ Second season } \\
\hline Zagazig & 9.64 & 10.95 & 20.59 & 5.71 & 6.21 & 11.92 & 68.75 & 76.33 & 72.70 \\
\hline Qnayat & 11.23 & 12.15 & 23.38 & 8.93 & 23 & 18.16 & 25.88 & 31 & 28.81 \\
\hline Menya A & 9.28 & 9.97 & 19.25 & & 81 & 12.88 & 52.94 & & 48 \\
\hline Mashtool & 8.75 & 9.33 & 18.08 & 6.4 & 7.11 & 13.54 & 36.11 & 31 & 3.57 \\
\hline Abu Hammad & 8.57 & 9.10 & 17.67 & 6.4 & 7.05 & 13.48 & 33.33 & 29.08 & 31.11 \\
\hline Belpis & 10.33 & 10.91 & 21.24 & 9.1 & 9.74 & 18.84 & 13.45 & 12 & 12.71 \\
\hline Diarb Negm & 8.78 & 9.12 & 17.90 & 7 & 7.59 & 14.60 & 25.32 & 20.16 & 22.64 \\
\hline Hehya & 9.71 & 10.45 & 20.16 & 7.5 & 8.42 & 15.92 & 29.52 & 24.11 & 26.66 \\
\hline Abu Kabir & 8.71 & 9.43 & 18.14 & 6.6 & 7.25 & 13.87 & 31.68 & 30.07 & 30.84 \\
\hline Faqous & 10.00 & 10.66 & 20.66 & 6.78 & 7.34 & 14.12 & 47.37 & 45.23 & 46.26 \\
\hline Mean & 9.50 & 10.21 & 19.71 & 7.06 & 7.68 & 14.73 & 34.63 & 32.99 & 33.78 \\
\hline
\end{tabular}

Straw yield also increased by using raised bed method compared to farmer practices with a difference between them were $3.24,1.37,1.56,1.62,0.25,2.59$, $2.53,2.22,1.88$ and $1.92 \mathrm{t} \mathrm{ha}^{-1}$ for the same order of different locations in Table 2 , respectively in the $1^{\text {st }}$ season as well as $4.74,2.92,3.16,2.22,2.05,1.17$, $1.53,2.03,2.18$ and $3.32 \mathrm{t} \mathrm{ha}^{-1}$ in the $2^{\text {nd }}$ one, respectively. Higher yield in raised bed-planted wheat was possibly due to wider spacing, which provided better light conditions in the canopy for photosynthesis than with wheat on flat layout. Connor et al. (2003) reported that raised bed sowing showed significantly higher grain yield as compared to flat method. Talukder (2004) and Ram et al. (2012) also reported that raised bed method showed significantly higher grain yield than the conventional one.

$\mathrm{N}$ uptake of wheat

Data in Table (3) illustrate that the raised bed treatment gave the highest values of nitrogen uptake for grain, straw and biological wheat yield compared to farmer practices in both seasons. The average mean values of all locations were $207.54,53.87$ and $261.41 \mathrm{~kg} \mathrm{~N} \mathrm{ha}^{-1}$ for grain, straw and biological wheat grown on raised bed, respectively compared with $149.47,35.39$ and $184.86 \mathrm{~kg}$

Fayoum J. Agric. Res. \& Dev., Vol. 29, No.1, January, 2015 
EFFECT OF RAISED BED PLANTING TECHNOLOGY ON

$\mathrm{N} \mathrm{ha}^{-1}$ for such parts of wheat grown on flat treatment, respectively in the first season. In the second season, the average mean values of raised bed were $219.21,57.48$ and $276.69 \mathrm{~kg} \mathrm{~N} \mathrm{ha}^{-1}$ for grain, straw and biological compared to $147.01,35.97$ and $182.98 \mathrm{~kg} \mathrm{~N} \mathrm{ha}^{-1}$ for the same parts of wheat grown on flat treatment, respectively. The relative increase of $\mathrm{N}$ uptake for wheat grown on raised bed were $38.85,52.22$ and $41.41 \%$ in the $1^{\text {st }}$ season, $49.28,50.99$ and $41.19 \%$ in the $2^{\text {nd }}$ one for grain, straw and biological yield, respectively.

Table (3) Effect of planting method on $N$ uptake of wheat grown in different locations in both seasons

\begin{tabular}{|c|c|c|c|c|c|c|c|c|c|}
\hline \multirow{3}{*}{ Locations } & \multicolumn{6}{|c|}{ N Uptake (kg/ha) } & \multirow{2}{*}{\multicolumn{3}{|c|}{ Relative increase (\%) }} \\
\hline & \multicolumn{3}{|c|}{ Raised beds } & \multicolumn{3}{|c|}{ Farmer practices } & & & \\
\hline & $n$ & Straw & Biol. & Grain & Straw & Biol. & Grain & Straw & Biol. \\
\hline \multicolumn{10}{|c|}{ First season } \\
\hline Zagazig & 258.48 & 69.31 & 327.79 & 167.79 & 41.05 & 208.84 & 54.05 & 68.84 & 56.96 \\
\hline Qnayat & 206.35 & 45.75 & 252.10 & 149.94 & 35.01 & 184.95 & 37.62 & 30.68 & 36.31 \\
\hline Menya Al_Qamh & 194.47 & 57.11 & 251.58 & 164.93 & 40.60 & 205.53 & 17.91 & 40.67 & 22.41 \\
\hline Mashtool & 167.47 & 48.02 & 215.49 & 120.81 & 27.73 & 148.54 & 38.62 & 73.16 & 45.07 \\
\hline Abu Hammad & 218.48 & 45.50 & 263.98 & 174.11 & 34.50 & 208.61 & 25.48 & 31.88 & 26.54 \\
\hline Belpis & 245.64 & 60.01 & 305.65 & 146.94 & 43.26 & 190.20 & 67.17 & 38.69 & 60.69 \\
\hline Diarb Negm & 135.66 & 39.16 & 174.82 & 96.39 & 20.66 & 117.05 & 40.74 & 89.59 & 49.36 \\
\hline Hehya & 240.38 & 59.13 & 299.51 & 161.09 & 44.36 & 205.45 & 49.22 & 33.28 & 45.78 \\
\hline Abu Kabir & 205.97 & 59.28 & 265.25 & 158.51 & 40.00 & 198.51 & 29.94 & 48.20 & 33.62 \\
\hline Faqous & 202.47 & 55.45 & 257.92 & 154.16 & 26.74 & 180.90 & 31.34 & 107.36 & 42.57 \\
\hline Mean & 207.54 & 53.87 & 261.41 & 149.47 & 35.39 & 184.86 & 38.85 & 52.22 & 41.41 \\
\hline \multicolumn{10}{|c|}{ Second season } \\
\hline Zagazig & & 4 & 295.00 & 126.33 & 31.46 & 15 & 84.09 & 54 & 88.14 \\
\hline Qnayat & 270.42 & 66.61 & 337.03 & 174.25 & 48.67 & 222.92 & 54.93 & 39.23 & 51.54 \\
\hline Menya Al_Q & & 50.45 & 274.17 & 121.37 & 31.34 & 152.71 & 83.53 & 62.67 & 79.32 \\
\hline Mashtool & 223.81 & 47.44 & 271.25 & 135.65 & 28.82 & 164.47 & 65.28 & 64.08 & 65.07 \\
\hline Abu Hammad & 210.81 & 50.26 & 261.07 & 126.49 & 37.71 & 164.20 & 66.67 & 36.52 & 59.87 \\
\hline Belpis & 232.49 & 64.53 & 297.02 & 191.25 & 49.16 & 240.41 & 21.55 & 32.17 & 23.71 \\
\hline Diarb Negm & 176.36 & 50.75 & 227.11 & 158.18 & 34.37 & 192.55 & 11.39 & 46.86 & 17.71 \\
\hline Hehya & 223.42 & 63.22 & 286.64 & 165.48 & 42.76 & 208.24 & 35.41 & 48.93 & 38.16 \\
\hline Abu Kabir & 205.15 & 55.46 & 260.61 & 142.35 & 25.55 & 167.90 & 43.93 & 115.54 & 54.77 \\
\hline Faqous & 195.22 & 61.74 & 256.96 & 128.76 & 29.82 & 158.58 & 52.86 & 112.26 & 63.75 \\
\hline Mean & 219.21 & 57.48 & 276.69 & 147.01 & 35.97 & 182.98 & 49.28 & \begin{tabular}{|l|}
50.98 \\
\end{tabular} & 41.19 \\
\hline
\end{tabular}

Also, data show that the nitrogen uptake of wheat grown on raised bed gave the values more than using traditional method by $58.07,18.48$ and $94.55 \mathrm{~kg} \mathrm{~N}^{-1}$ in the first season and 72.20, 21.51 and $93.71 \mathrm{~kg} \mathrm{~N} \mathrm{ha}^{-1}$ in the second season for grain, straw and biological yield, respectively. These results coincide with those of Hossain, et al., (2004) who found that using raised beds compared to conventional method, nitrogen uptake and efficiency can be increased. They added that the maximum $\mathrm{N}$ uptake by the grain and straw was recorded in raised bed technology.

$P$ uptake of wheat

Data in Table (4) demonstrate that phosphorus uptake of different wheat parts was affected by sowing on raised beds compared to traditional method (flat)

Fayoum J. Agric. Res. \& Dev., Vol. 29, No.1, January, 2015 
Osman, E. A.M et al.,

in both seasons. The average mean values of all locations were 34.15, 21.27 and $55.42 \mathrm{~kg} \mathrm{P} \mathrm{ha}^{-1}$ for grain, straw and biological wheat yield grown on raised bed, respectively compared to $27.49,17.03$ and $44.52 \mathrm{~kg} \mathrm{P} \mathrm{ha}^{-1}$ for those grown on traditional method treatment, respectively in the first season. Whereas, 36.27, 23.72 and $59.99 \mathrm{~kg} \mathrm{P} \mathrm{ha}^{-1}$ compared to $26.99,17.00$ and $43.98 \mathrm{~kg} \mathrm{P}^{-1}$ for grain, straw and biological wheat grown on raised bed and traditional method treatment, respectively in the second season. On the other hand, the relative increase of phosphorus uptake for wheat grown on raised bed were 24.23, 24.90 and $24.48 \%$ in the $1^{\text {st }}$ season, $34.41,39.53$ and $36.39 \%$ in the $2^{\text {nd }}$ one for grain, straw and biological yield, respectively. Besides, results reveal that the $\mathrm{P}$ uptake of wheat grown on raised bed gave the values higher than that using farmer practices by $6.66,4.24$ and $10.90 \mathrm{~kg} \mathrm{P} \mathrm{ha}^{-1}$ in the first season as well as $9.28,6.72$ and $16.00 \mathrm{~kg}$ $\mathrm{P} \mathrm{ha}^{-1}$ for grain, straw and biological yield, respectively in the second season. These results are in agreement with those obtained by Talukder, et al., (2004) who stated that the change from sowing wheat on the flat to raised beds increased nutrient uptake and efficiency.

Table (4) Effect of planting method on $P$ uptake of wheat grown in different locations in both seasons

\begin{tabular}{|c|c|c|c|c|c|c|c|c|c|}
\hline \multirow{3}{*}{ Locations } & \multicolumn{6}{|c|}{ P Uptake (kg/ha) } & \multirow{2}{*}{\multicolumn{3}{|c|}{ Relative increase (\%) }} \\
\hline & \multicolumn{3}{|c|}{ Raised beds } & \multicolumn{3}{|c|}{ Farmer practices } & & & \\
\hline & Grain & Straw & Biol. & Grain & Straw & Biol. & Grain & Straw & Biol. \\
\hline \multicolumn{10}{|c|}{ First season } \\
\hline Zagazig & 42.00 & 22.71 & 64.71 & 32.03 & 15.60 & 47.63 & 31.13 & 45.54 & 35.85 \\
\hline Qnayat & 31.81 & 21.96 & 53.77 & 28.49 & 18.67 & 47.16 & 11.65 & 17.62 & 14.02 \\
\hline Menya Al_Qamh & 34.57 & 23.23 & 57.80 & 30.63 & 19.49 & 50.12 & 12.86 & 19.20 & 15.33 \\
\hline Mashtool & 33.49 & 16.59 & 50.08 & 23.13 & 13.51 & 36.64 & 44.79 & 22.78 & 36.67 \\
\hline Abu Hammad & 29.99 & 17.29 & 47.28 & 29.02 & 14.16 & 43.18 & 3.34 & 22.10 & 9.50 \\
\hline Belpis & 37.10 & 24.00 & 61.10 & 25.49 & 18.30 & 43.79 & 45.55 & 31.16 & 39.53 \\
\hline Diarb Negm & 25.78 & 17.09 & 42.87 & 17.14 & 11.02 & 28.16 & 50.41 & 55.06 & 52.23 \\
\hline Hehya & 39.06 & 18.28 & 57.34 & 32.22 & 14.50 & 46.72 & 21.23 & 26.03 & 22.72 \\
\hline Abu Kabir & 34.92 & 26.68 & 61.60 & 28.10 & 21.60 & 49.70 & 24.27 & 23.50 & 23.94 \\
\hline Faqous & 32.74 & 24.86 & 57.60 & 28.68 & 19.86 & 48.54 & 14.16 & 25.16 & 18.66 \\
\hline Mean & 34.15 & 21.27 & 55.42 & 27.49 & 17.03 & 44.52 & 24.23 & 24.90 & 24.48 \\
\hline \multicolumn{10}{|c|}{ Second season } \\
\hline Zagazig & 37.59 & 26.28 & 63.87 & 23.99 & 11.80 & 35.79 & 56.70 & 122.73 & 78.47 \\
\hline Qnayat & 43.82 & 29.16 & 72.98 & 34.81 & 15.69 & 50.50 & 25.88 & 85.84 & 44.51 \\
\hline Menya Al_Qamh & 34.34 & 24.93 & 59.27 & 23.06 & 16.34 & 39.41 & 48.92 & 52.50 & 50.40 \\
\hline Mashtool & 30.61 & 21.47 & 52.08 & 22.49 & 13.51 & 36.00 & 36.11 & 58.90 & 44.66 \\
\hline Abu Hammad & 31.70 & 20.93 & 52.63 & 21.85 & 15.51 & 37.36 & 45.10 & 34.95 & 40.88 \\
\hline Belpis & 41.31 & 24.82 & 66.13 & 35.50 & 23.38 & 58.88 & 16.36 & 6.18 & 12.32 \\
\hline Diarb Negm & 33.37 & 19.33 & 52.70 & 28.03 & 18.22 & 46.25 & 19.05 & 6.10 & 13.95 \\
\hline Hehya & 37.87 & 22.99 & 60.86 & 29.24 & 22.73 & 51.97 & 29.52 & 1.13 & 17.10 \\
\hline Abu Kabir & 33.10 & 21.69 & 54.79 & 26.46 & 18.85 & 45.31 & 25.09 & 15.06 & 20.92 \\
\hline Faqous & 38.98 & 25.58 & 64.57 & 24.42 & 13.95 & 38.36 & 59.65 & 83.45 & 68.30 \\
\hline Mean & 36.27 & 23.72 & 59.99 & 26.99 & 17.00 & 43.98 & 34.41 & 39.53 & 36.39 \\
\hline
\end{tabular}

Fayoum J. Agric. Res. \& Dev., Vol. 29, No.1, January, 2015 
EFFECT OF RAISED BED PLANTING TECHNOLOGY ON

\section{K uptake of wheat}

Results in Table (5) show that the potassium uptake of wheat grain, straw and biological yield was increased by using raised bed compared with farmer practices in both seasons. The average mean values were 39.28, 147.15 and $186.42 \mathrm{~kg}$ potassium ha ${ }^{-1}$ for grain, straw and biological wheat yield grown on raised bed, respectively compared with $24.70,99.51$ and $124.22 \mathrm{~kg} \mathrm{~K}^{-1}$ for those of wheat grown on flat treatment, respectively in the first season. While, values were $42.83,189.74$ and $232.57 \mathrm{~kg} \mathrm{~K}^{-1}$ compared to 31.37 , 134.96 and $166.33 \mathrm{~kg} \mathrm{~K} \mathrm{ha}^{-1}$ for grain, straw and biological wheat grown on raised bed and flat method treatment, respectively in the second one. Generally, the relative increase of $\mathrm{K}$ uptake for wheat grown on raised bed were 59.00, 47.87 and $50.08 \%$ in the $1^{\text {st }}$ season, $36.53,40.59$ and $39.82 \%$ for grain, straw and biological yield, in the $2^{\text {nd }}$ one, respectively. These findings are in agreement with those obtained by Talukder, et al., (2004).

Table (5) Effect of planting method on $K$ uptake of wheat grown in different locations in both seasons

\begin{tabular}{|c|c|c|c|c|c|c|c|c|c|}
\hline \multirow{3}{*}{ Locations } & \multicolumn{6}{|c|}{ K Uptake (kg/ha) } & \multicolumn{3}{|c|}{ Relative increase $(\%)$} \\
\hline & \multicolumn{3}{|c|}{ Raised beds } & \multicolumn{3}{|c|}{ Farmer practices } & \multirow[b]{2}{*}{ Grain } & \multirow[b]{2}{*}{ Straw } & \multirow[b]{2}{*}{ Biol. } \\
\hline & & IW & Biol. & Grain & & 1. & & & \\
\hline \multicolumn{10}{|c|}{ First season } \\
\hline Zagazig & 47.39 & 188.81 & 236.20 & 24.41 & 100.16 & 124.57 & 94.16 & 8.50 & 89.61 \\
\hline Qnayat & 36.97 & 139.08 & 176.05 & 3.24 & 98.03 & 121.27 & 59.08 & 41.88 & 45.17 \\
\hline Ienya Al_Qamh & & 144.23 & 183.12 & 26.70 & & & 45.65 & & 1.05 \\
\hline Mashtool & 5.21 & 134.44 & 169.65 & 22.49 & 91.72 & 114.21 & 56.56 & 46.58 & 48.54 \\
\hline Abu Hammad & 27 & .96 & 182.23 & 30.68 & & 146.61 & 31.27 & & 4.29 \\
\hline Belpis & 4.11 & 156.01 & 200.13 & 26.99 & 106.50 & 133.49 & 63.45 & 46.50 & 49.92 \\
\hline Diarb Negm & 1.20 & 104.66 & 135.87 & 16.28 & 60.59 & 76.87 & 91.67 & 72.75 & 76.75 \\
\hline Hehya & 4.07 & 167.70 & 211.77 & 28.09 & 114.30 & \begin{tabular}{|l|}
142.39 \\
\end{tabular} & 56.90 & 46.72 & 48.73 \\
\hline Abu Kabir & 7.61 & 151.16 & 188.78 & 23.06 & 102.40 & 125.46 & 63.13 & 47.62 & 50.47 \\
\hline $\mathrm{F}$ & 05 & 143.40 & 180.45 & 25.10 & 10 & 127.47 & 47.63 & 40.07 & 41.56 \\
\hline in & & 15 & 186.42 & 24.70 & 99 & 124.22 & 59.00 & 47.87 & 50.08 \\
\hline \multicolumn{10}{|c|}{ Second season } \\
\hline Zagazig & 42.06 & 208.05 & 250.11 & 23.05 & 112.40 & 135.45 & 82.47 & 85.10 & 84.65 \\
\hline$Q$ & & 2 & 281 & 37.65 & & 25 & 35.64 & .74 & 42.20 \\
\hline enya Al_Qa & 8.81 & 190.43 & 229.24 & 26.48 & 117.13 & 143.61 & 46.56 & 62.58 & 59.63 \\
\hline Mashtool & 41.35 & 176.39 & 217.74 & 27.81 & 119.45 & 147.26 & 48.69 & 47.67 & 47.86 \\
\hline bu Hamms & 44 & 169.26 & 210.70 & 29.21 & 12 & 151.18 & 41.87 & 38.77 & 39.37 \\
\hline Belpis & 46.95 & 198.56 & 245.51 & 41.05 & 180.19 & 221.24 & 14.37 & 10.19 & 10.97 \\
\hline iarb Negn & & 171.46 & 207.87 & 33.89 & 137.38 & 171.27 & 7.44 & 24.81 & 21.37 \\
\hline Hehya & 43.79 & 193.33 & 237.12 & 34.62 & 147.35 & 181.97 & 26.49 & 31.20 & 30.31 \\
\hline Abu Kabir & 39.91 & 165.03 & 204.94 & 30.07 & 124.70 & 154.77 & 32.72 & 32.34 & 32.42 \\
\hline Faqous & 46.53 & 194.01 & 240.54 & 29.84 & 128.45 & \begin{tabular}{|l|}
158.29 \\
\end{tabular} & 55.93 & 51.04 & 51.96 \\
\hline Mean & 42.83 & 189.74 & 232.57 & 31.37 & 134.96 & 166.33 & 36.53 & 40.59 & 39.82 \\
\hline
\end{tabular}

Fayoum J. Agric. Res. \& Dev., Vol. 29, No.1, January, 2015 
Results in Table (6) demonstrate that the raised bed treatment gave better saving in irrigation water more than the farmer practices treatment in both seasons. The applied irrigation water varied from 4705 to 3991 with mean average $4249 \mathrm{~m}^{3} \mathrm{ha}^{-1}$ for wheat sowing on the raised bed compared with 5876 to 5000 with mean average $5605 \mathrm{~m}^{3} \mathrm{ha}^{-1}$ for sowing on flat treatment in the first season. The applied water for wheat sowing on raised bed was lower than flat treatment by $1356 \mathrm{~m}^{3} \mathrm{ha}^{-1}$ with savings in irrigation water by $24.1 \%$ in the first season. This might be due to the reduction of surface evaporation in the raised bed compared to the flat technique. Abd El-Halim and Abd El-Razek, (2014) demonstrated that applying water through the raised bed treatment saved about $42 \%$ (mean over two seasons) of the water applied, comparable with the conventional flat treatment. Furthermore, Aggarwal and Goswami, (2003) and Ram et al., (2005) have also reported similar or higher yields of wheat on raised beds compared with flat with $30-50 \%$ reduction in irrigation water use on beds.

Table (6) Effect of planting method on applied water $\left(\mathrm{m}^{3} \mathrm{ha}^{-1}\right)$ of wheat grown in different locations in both seasons

\begin{tabular}{|c|c|c|c|c|}
\hline \multirow{3}{*}{ Location } & \multicolumn{2}{|c|}{$\begin{array}{l}\text { Applied water } \\
\text { (m3/ha.) }\end{array}$} & \multicolumn{2}{|c|}{$\begin{array}{c}\text { Rate of savings in irrigation } \\
\text { water }\end{array}$} \\
\hline & \multirow{2}{*}{$\begin{array}{c}\text { Raised } \\
\text { beds }\end{array}$} & \multirow{2}{*}{$\begin{array}{c}\text { Farmer } \\
\text { practices }\end{array}$} & & \\
\hline & & & $\mathrm{m}^{3} \mathrm{ha}^{-1}$. & $\%$ \\
\hline \multicolumn{5}{|c|}{ First season } \\
\hline Zagazig & 4705 & 5626 & 921 & 16.4 \\
\hline Qnayat & 4032 & 5674 & 1642 & 28.9 \\
\hline Menya Al_Qamh & 4315 & 5876 & 1561 & 26.6 \\
\hline Mashtool & 4241 & 5112 & 871 & 17.0 \\
\hline Abu Hammad & 4084 & 5781 & 1697 & 29.4 \\
\hline Belpis & 3991 & 5000 & 1009 & 20.2 \\
\hline Diarb Negm & 4348 & 5712 & 1364 & 23.9 \\
\hline Hehya & 4058 & 5681 & 1623 & 28.6 \\
\hline Abu Kabir & 4206 & 5781 & 1576 & 27.3 \\
\hline Faqous & 4513 & 5807 & 1295 & 22.3 \\
\hline Mean & 4249 & 5605 & 1356 & 24.1 \\
\hline \multicolumn{5}{|c|}{ Second season } \\
\hline Zagazig & 3977 & 4869 & 892 & 18.4 \\
\hline Qnayat & 3920 & 5062 & 1142 & 22.6 \\
\hline Menya Al_Qamh & 3937 & 5310 & 1373 & 25.9 \\
\hline Mashtool & 4046 & 5341 & 1295 & 24.3 \\
\hline Abu Hammad & 4006 & 5038 & 1033 & 20.5 \\
\hline Belpis & 3722 & 4805 & 1083 & 22.6 \\
\hline Diarb Negm & 4017 & 5376 & 1359 & 25.3 \\
\hline Hehya & 3832 & 4967 & 1135 & 22.9 \\
\hline Abu Kabir & 3801 & 5372 & 1571 & 29.3 \\
\hline Faqous & 3784 & 5019 & 1235 & 24.6 \\
\hline Mean & 3904 & 5116 & 1212 & 23.7 \\
\hline
\end{tabular}

Fayoum J. Agric. Res. \& Dev., Vol. 29, No.1, January, 2015 
Concerning the second season, the applied irrigation water was diverse from 4046 to 3722 with mean average $3904 \mathrm{~m}^{3} \mathrm{ha}^{-1}$ for wheat sowing on the raised bed compared with 5376 to 4805 with mean average $5116 \mathrm{~m}^{3} \mathrm{ha}^{-1}$ for sowing on traditional treatment. On the other hand, the applied water for wheat sowing on raised bed was inferior to flat treatment by 1356 and $1212 \mathrm{~m}^{3} \mathrm{ha}^{-1}$ with savings in irrigation water by 24.1 and $23.7 \%$ in the first and second season, respectively. The hypothesis of raised bed method is to reduce water losses and decreasing evaporation, deep percolation, surface run-off, and seepage. These advantages come from the fact that irrigation water advances faster in raised bed than in flat treatment and less water percolation loss happens. These findings are in agreement with those obtained by Ram, et al. (2013) who found that the wheat grown on raised beds had $18.8 \%$ lower applied water than flat method. Also, Ram et al. (2012) reported lower water use and high WUE in bed-planted soybean and wheat.

\section{CONCLUSION}

Finally, this study demonstrates that raised beds technology increased wheat yield by $28.92 \%$ when compared with conventional method (flat). Nitrogen, phosphorus and potassium uptake by the grain and straw was higher on raised bed when compared with flat. Raised beds also reduced the irrigation water requirement by $23.90 \%$. Thus, in warmer areas such as Egypt where water resources are becoming limited and nutrient uptake and efficiencies are low, the use of raised beds system would be a distinct advantage.

\section{REFERENCES}

Abd El-Halim A. A. and Abd El-Razek, U. A. (2014). Effect of different irrigation intervals on water saving, water productivity and grain yield of maize (Zea mays L.) under the double ridge-furrow planting technique, Archives of Agron. and Soil Sci., 60: 587-596,

Aggarwal, P. and Goswami, B. (2003). Bed planting system for increasing water use efficiency of wheat (Triticum aestivum) grown in Inceptisol (Typic Ustochrept). Indian Journal of Agric. Sci. 73:422-425.

Ahamd R.N, Arshad M. and Shahid M.A. (2011). Raised bed technology for crop water productivity of maize and cotton. ICID 21st International Congress on Irrigation and Drainage, 2011 Oct 15- 23; Tehran; p. 171-180.

Ahmad N, Arshad M. and Shahid M.A. (2009). Bed-furrow system to replace conventional flood irrigation in Pakistan. Proceedings of $59^{\text {th }}$ IEC Meeting and $20^{\text {th }}$ ICID Conference held at New Delhi, India, 2009 611 December; New Delhi.

Akbar G, Hamilton G, and Steven R. (2010). Permanent raised bed configurations and renovation methods affect crop performance. $19^{\text {th }}$ World Congress of Soil Sci., Soil Solutions for a Changing World, 2010 Aug 1-6; Brisbane; p. 171-174.

Fayoum J. Agric. Res. \& Dev., Vol. 29, No.1, January, 2015 
Alam, M. S. (2012). Effect of sowing patterns and nitrogen rates on quality traits and yield of wheat. J. Environ. Sci. \& Natural Resources, 5: 267272.

Black, C.A. (1982). "Methods of Soil Analysis." Amer. Sec. Agron. Inc. Publisher. Madison, Wisconsin., U S A.

Buttar G.S., Thind H.S., and Aujla M.S. (2006). Methods of planting and irrigation at various levels of nitrogen affect the seed yield and water use efficiency in transplanted oilseed rape (Brassica napus L.). Agric Water Manage. 85:253-260.

Connor, D.J., Timsina J. and Humphreys E. (2003). Prospects for permanent beds for rice-wheat systems. In: Ladha , J.K. et al., (eds). Improving the productivity and sustainability of rice-wheat systems: Issues and Impacts. ASA. Madison, Wisconsin, USA.

Fahong, W., Xuquing W.and Sayre K. D. (2003). Comparison Study on two Different Planting Methods for Winter Wheat in China. Bed planting course, CIMMYT. Mexico

Harms, T.E. and Konschuh M.N. (2010). Water savings in irrigated potato production by varying hill- furrow or bed-configuration. Agric Water Manage. 97:1399-1404.

Hobbs P. R.Y., Sing G.S., Giri J., Lauren G. and Dusbury, J. M. (2000). Direct seeding and reduced tillage options in the ricewheat systems of the Indo-Gangetic plain of South Asia. Paper presented at IRRI workshop, Bankok, Thailand, 25- 28 January, 2000.

Hossain, I., Islam, K., Abu Sufian, M.d., Meisner, C. A and Islam M.d.S. (2006) . Effect of planting method and nitrogen levels on the yield and yield attributes of wheat. J. Bio-Sci. 14: 127-130,

Hossain, M.I., Craig Meisner J.M., Duxbury J.G., Lauren M.M., Rahman, M.M., Meer and Rashid M.H. (2004). Use of raised beds for increasing wheat production in rice-wheat cropping systems. "New directions for a diverse planet". Edited by RA Fischer. Proceedings of the 4th International Crop Science Congress. Brisbane, Australia, 26 September - 1 October 2004

Hussain, M. I. and Shah S. H. ( 2002).Growth, yield and quality response of three wheat (Triticum aestivum L.) varieties to different levels of N, P and K. Int. J. of Agri. and Bio., 4: 362-364.

Ram, H., Singh Y., Saini K. S., Kler D. S. and Timsina J. (2013) . Tillage and planting methods effects on yield, water use efficiency and profitability of soybean-wheat system on a loamy sand soil. Expl Agric.: page 1 of 19 C-Cambridge University Press doi:10.1017/S0014479713000264.

Ram, H., Yadvinder-Singh, Saini K. S., Kler D. S., Timsina, J. and Humphreys E. J. (2012). Agronomic and economic evaluation of permanent raised beds, no tillage and straw mulching for an irrigated

Fayoum J. Agric. Res. \& Dev., Vol. 29, No.1, January, 2015 
maize-wheat system in northwest India. Experimental Agriculture 48:21-38.

Ram, H., Yadvinder-Singh, Timsina J., Humphreys E., Dhillon S. S., Kumar K. and Kler D. S. (2005). Performance of upland crops on raised beds in northwest India. In Proceedings of Workshop on Evaluation and Performance of Permanent Raised Bed Cropping Systems in Asia, Australia and Mexico, 1-3 March, Griffith, NSW, Australia, ACIAR Proceedings No. 121, pp. 41-58.

Ryan, J., Garabet S., Harmsen K. and Rashid A. (1996). A Soil and Plant Analysis Manual Adapted for the West Asia and North Africa Region. ICARDA, Aleppo, Syria. 140pp.

Sayre K. D. and Morens Romos O.H., (1997). Application of raised bed planting system to wheat. Wheat Program Special Res.31. CIMMYT, Mexico. P $14-22$.

Shapiro, Y. (2009). Monsanto's plan and prospects for wheat improvement through breeding and biotechnology. In: Reynolds M. and Eaton D., eds. Book of Abstract. Complementary strategies to raise wheat yield potential. Workshop held at CIMMYT, E. Baton, Mexico, DF., CIMMYT.

Swelam, A. and Atta Y. (2011). New approach of farm management under surface irrigation to improve water saving and productivity. New Horizons in Sci. Technol. 1:76-83.

Taleghani, D.F., Tohidloo G., Gohari J., Habibi D., Sadeghian Y. and Mesbah M. (2004). Improvement of water productivity in surface irrigation system by changing the plant spacing in sugar beet cultivation [Internet]. In: Fischer T, Turner N, Angus J, McIntyre L, Robertson M, Borrell A, Lloyd D, editors. New directions for a diverse planet: Proceedings 4th International Crop Science Congress (ICSC), 2004 Sep 26-Oct 2, Brisbane, Australia. Available from: www.cropscience.org.au.

Talukder, A.S.M., Meisner C., Kabir M.J., Hossain A.B.S. and Rshid M. H.( 2004). Productivity of multi-crops sown on permanent raised beds in the tropics. New directions for a diverse planet: Proceedings of the 4th International Crop Science Congress Brisbane, Australia, 26 Sep 1 Oct 2004 | ISBN 1920842209 | www.cropscience.org.au

Talukder, A.S.M. (2004). Rice-wheatmaize+ mungbean cropping sequence in a permanent bed planting system. Paper presented at Internal review Workshop in 2002 at BARI (Bangladesh Agric. Res. Inst.), Joydebpur, Gazipur. pp. 31-33.

Zhang, X., Maa L., Gilliam F.S., Wang Q. and Li C. (2012). Effects of raised-bed planting for enhanced summer maize yield on rhizosphere soil microbial functional groups and enzyme activity in Henan Province, China. Field Crop Res. 130:28-37.

Fayoum J. Agric. Res. \& Dev., Vol. 29, No.1, January, 2015 
تاثير تقتية الزراعة على مصاطب على الانتاجية و امتصاص المغذيات الكبرى لقمح الخبز وتوفير

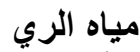

عصام الدين عبدالعزيز محمد عثمان*- عبدالله عبدالمحسن سويلم**ــ منال عبدالصمد حسن**-

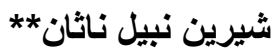

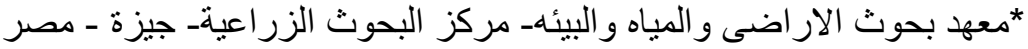

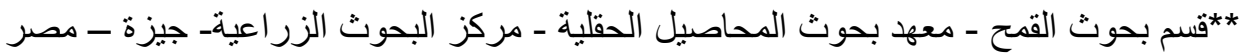

أقيمت نجربة حقلية لدى المزارعين لمعرفة ناثير طريقة الزراعة على مصاطب مقارنة

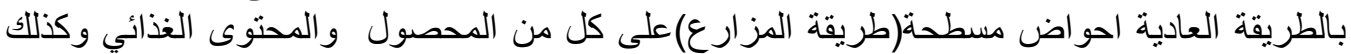

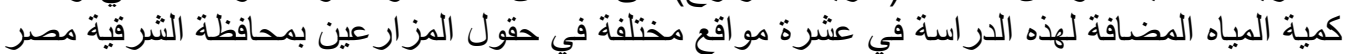

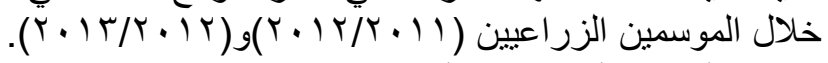

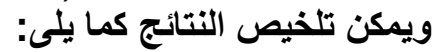

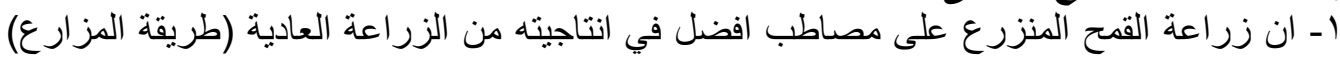

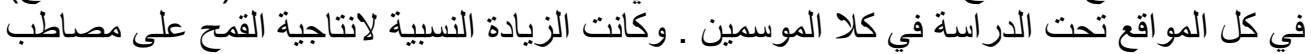

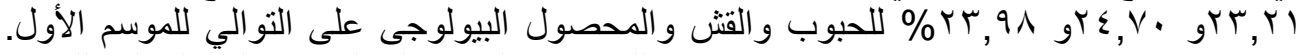

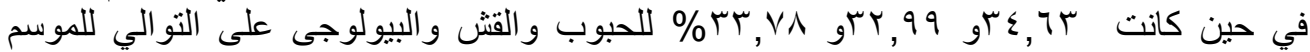

rـ أعطت معاملة الزراعة على مصاطب افضل القيم للممنص من النيتروجين و الفوسفور و البوتاسيوم

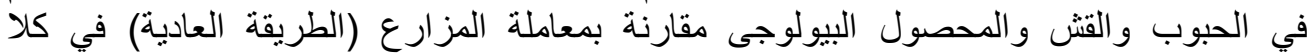

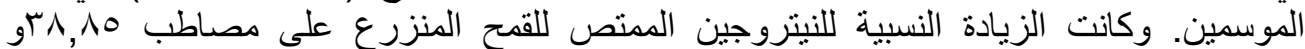

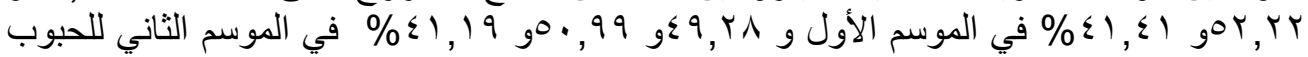

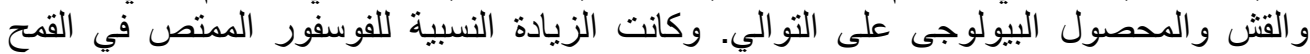

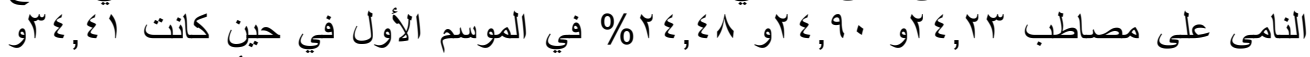

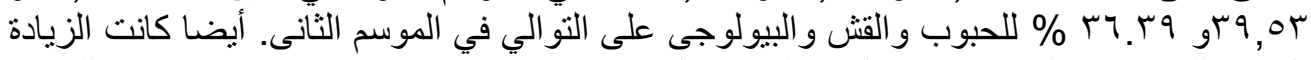

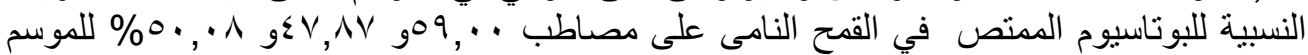

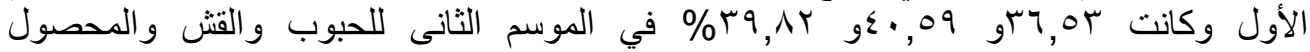

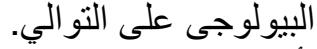

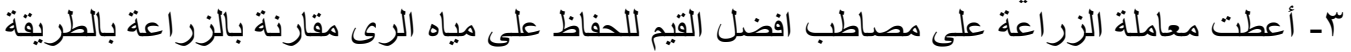

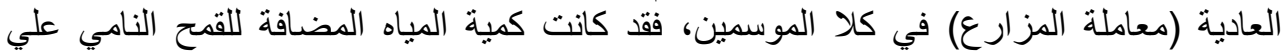

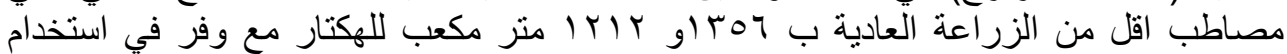

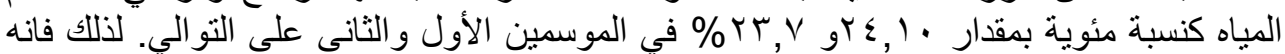

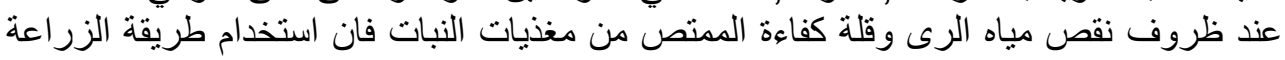
على مصاطب تعتبر ضرورة ملحه. 